\section{Pemanfaatan Alokasi Dana \\ Desa Dalam Meningkatkan \\ Perekonomian Masyarakat \\ Desa Tunujungtirto \\ Kecamatan Singosari Malang}

\author{
Ika Devy Pramudiana 1), \\ Nihayatus Sholichah ${ }^{2)}$ \\ 1 Fakultas Ilmu Administrasi, \\ Universitas Dr. \\ Soetomo Surabaya \\ 2 Fakultas Ilmu Administrasi, \\ Universitas Dr. \\ Soetomo Surabaya
}

Korespodensi Penulis. E-mail: ik.pramudiana@gmail.com

\begin{abstract}
Abstrak
Desa memiliki peran yang sangat penting dalam menyelenggarakan urusan pemerintahan umum desa serta pelayanan kepada masyarakat secara lebih terarah dan fokus terutama program kegiatan pemerintah desa yang bersentuhan langsung dengan kepentingan masyarakat desa dengan dasar pertimbangan bahwa akan memberikan suatu kehidupan yang layak dan makmur bagi masyarakat desa. Berbagai masalah timbul di desa maka untuk membantu mempercepat pembangunan pedesaan, pemerintah kemudian memberikan program bantuan Alokasi Dana Desa (ADD). Salah satu desa yang mendapatkan ADD adalah desa Tunjungtirto kecamatan Singosari Malang. Dalam dana desa Tunjungtirto terbagi menjadi empat bagian yaitu perekonomian, sarana prasarana dasar, sarana dan prasarana pelayanan sosial dasar dan
\end{abstract}

pemberdayaan. Dari empat bagian alokasi dana desa Alokasi di bidang ekonomi pada desa Tunjungtirto ini diharapkan mampu mensejahterakan masyarakatnya dan dalam rangka mengurangi kemiskinan di pedesaan karena penguatan basis ekonomi rakyat yang bersumber pada asset desa merupakan pilihan menuju kemandirian. Tujuan penelitian adalah untuk memberikan gambaran, sejauh mana pemanfaatan alokasi dana desa dalam meningkatkan perekonomian masyarakat. Penelitian ini menggunakan pendekatan yuridis normatif dengan menggunakan analisis Undang-Undang Desa, kemudian menggunakan pendekatan masalah dengan menggunakan case of study (studi kasus). Selanjutnya menggunakan studi kepustakaan dengan cara membaca, mengutip, menyalin dan menganalisa. Ada beberapa kesimpulan dari hasil penelitian ini yaitu pemanfaatan ADD pada bidang ekonomi masyarakat adalah tersedianya tempat penjualan berbagai hasil produksi rumah tangga masyarakat Desa Tunjungtirto, dan juga dengan ADD di bidang ekonomi di gunakan untuk kegiatan peningkatan peranan wanita melalui perwujudan kesetaraan gender dan Pemberdayaan dan Kesejahteraan Keluarga (PKK) Desa. Dalam mendorong peningkatan sosial dan ekonomi masyarakat dapat dilakukan melalui kegiatan-kegiatan dari PKK, yang bertujuan meningkatkan pendapatan keluarga dengan kemandirian.

Kata Kunci: Alokasi Dana Desa, Masyarakat desa, Perekonomian desa. 


\begin{abstract}
Villages have a very important role in carrying out general village government affairs and services to the community in a more directed and focused way especially on village government activities that come in direct contact with the interests of village communities on the basis that they will provide a decent and prosperous life for the village

various household products of the Tunjungtirto Village community, and also with $A D D$ in the economic field used to increase women's role through the realization of gender equality and Family Welfare (PKK) Village. In encouraging an increase in the social and economic community can be done through activities from the PKK, which aims to increase family income with independence.
\end{abstract} community. Various problems arose in the village so to help accelerate rural development, the government then provided a Village Fund Allocation (ADD) assistance program. One of the villages that received $A D D$ was Tunjungtirto village, Singosari district, Malang. In Tunjungtirto village funds are divided into four parts, namely the economy, basic infrastructure, facilities \& infrastructure, basic social services and empowerment. Of the four sections of village fund allocation, the allocation in the economic field to Tunjungtirto village is expected to be able to prosper the community and in order to reduce rural poverty because the strengthening of the people's economic base sourced from village assets is a choice towards independence. The purpose of the study is to provide an overview, the extent to which the use of village funds allocation in improving the economy of the community. This study uses a normative juridical approach using Village law analysis, then use a problem approach using a case of study. Next, use library research by reading, quoting, copying and analyzing. There are some conclusions from the results of this study, that the use of ADD in the community economy is the availability of a place to sell
Keywords: Allocation of village funds, Village communities, Village economy.

\section{A. PENDAHULUAN}

Pembangunan nasional merupakan upaya yang dilakukan pemerintah untuk mengembangkan proses keseluruhan sistem penyelenggaraan Negara, Upaya pembangunan nasional dari paling yang terkecil diwujudkan melalui pembangunan desa, karena pembangunan selama ini hanya terkesan di kota saja. Berdasarkan Peraturan Pemerintah No. 60 Tahun 2014 tentang Dana Desa yang bersumber dari APBN, dengan luasnya lingkup kewenangan desa dan dalam rangka mengoptimalkan penggunaan Dana Desa, maka penggunaan Dana Desa diprioritaskan untuk membiayai pembangunan dan pemberdayaan masyarakat Desa. Penetapan prioritas penggunaan dana tersebut tetap sejalan dengan kewenangan yang menjadi tanggungjawab Desa.

Desa merupakan organisasi terkecil dan penting dalam suatu 
Negara karena berhadapan secara langsung dengan masyarakat. Berbagai masalah timbul di desa seperti adanya ketimpangan pembangunan, masalah pertanian, dan juga masalah perekonomian maka untuk membantu mempercepat pembangunan pedesaan, pemerintah kemudian memberikan program bantuan Alokasi Dana Desa (ADD). Di Indonesia Jumlah kecamatan dan kelurahan/desa yang terdaftar setiap tahun mengalami peningkatan. Berdasarkan Permendagri no.137 tahun 2017 tentang Kode dan Data Wilayah Administrasi Pemerintahan, terdapat 74.957 desa di Indonesia (www.kompasiana.com).

Salah satu desa yang mendapatkan ADD adalah desa Tunjungtirto kecamatan Singosari Malang, Pada Desa Tunjungtirto Besaran Alokasi Dana Desa ADD terus naik tiap tahunnya, seperti yang terlihat pada tabel 1 .

Tabel 1. Alokasi Dana Desa, Desa Tunjungtirto Malang

\begin{tabular}{|c|c|c|c|}
\hline ADD & Tahun & Tahun & Tahun \\
/DD & 2015 & 2016 & 2017 \\
\hline ADD & 473.534 .000 & 484.978 .000 & 488.931 .000 \\
\hline DD & 289.759 .000 & 650.402 .000 & 828.978 .000 \\
& & & \\
\hline
\end{tabular}

Sumber: Data Desa Tunjungtirto Malang

Dengan adanya Dana Desa tersebut, maka pemerintah Desa dituntut untuk mengelola dana desa dengan efektif dan akuntabel efektif yang dimaksud adalah sejauh mana target (kuantitas, kualitas dan waktu) yang telah dicapai oleh pemerintah Desa dalam pemanfaatan dana desa khususnya dalam peningkatan perekonomian masyarakat. Sedangkan Akuntabel yang dimaksud adalah tingkat transparansi dari keberhasilan atau kegagalan yang telah di capai oleh pemerintah desa dalam pemanfaatan dana desa.

Undang-Undang Nomor 6 Tahun 2014 Pasal 2 Tentang Desa, Penggunaan Dana Desa berdasarkan Pasal 25 Peraturan Menteri Keuangan Nomor 247 Tahun 2015, yaitu Dana Desa di prioritaskan untuk membiayai pembangunan dan pemberdayaan masyarakat yang pelaksanaannya diutamakan secara swakelola dengan menggunakan sumber daya/bahan baku lokal, dan diupayakan dengan lebih banyak menyerap tenaga kerja dari masyarakat setempat.

Hal ini sesuai dengan sasaran dan tujuan Desa Tunjungtirto untuk yaitu "Mewujudkan masyarakat Tunjungtirto yang mandiri dan produktif". maka tujuan pembangunan periode tahun 2016-2019 adalah Meningkatkan kesejahteraan masyarakat dibidang perekonomian. Meningkatkan potensi masyarakat dan pemberdayaan dalam memanfaatkan sumber daya alam 
Vol.1 No.1 Juni 2019

yang ada. Meningkatkan kemampuan masyarakat dalam memenuhi kebutuhannya serta menyelesaikan masalahnya sendiri.

$$
\text { Adapun, sasaran }
$$

pembangunan tahun 2016-2019 adalah meningkatkan kemampuan/potensi lokal masyarakat Desa Tunjungtirto di segala bidang. Maka penelitian ini dilakukan untuk memberikan gambaran, sejauh mana pemanfaatan alokasi dana desa dalam meningkatkan perekonomian masyarakat. Untuk itu peneliti tertarik untuk melakukan penelitian yang bertajuk "pemanfaatan alokasi dana desa dalam meningkatkan perekonomian masyarakat desa Tunjungtirto kecamatan Singosari Kabupaten Malang.

\section{B. TEORI (Literature Review) 1. Alokasi dana desa}

Alokasi Dana Desa (ADD) adalah dana yang bersumber dari Anggaran Pendapatan dan Belanja Daerah (APBD) Kabupaten yang dialokasikan dengan tujuan pemerataan kemampuan keuangan antar Desa untuk mendanai kebutuhan Desa dalam rangka penyelenggaraan Pemerintahan dan pelaksanaan pembangunan serta pelayanan masyarakat. Alokasi Dana Desa diperoleh dari dana perimbangan APBN yang diterima oleh Kabupaten/Kota dalam Anggaran Pendapatan dan Belanja Daerah (APBD) setelah dikurangi Dana Alokasi Khusus (DAK) sebesar $10 \%$, hal ini tertera pada Pasal 72 Undang Undang Nomor 6 tahun 2014 tentang Desa. Desa mempunyai sumber pendapatan berupa pendapatan asli Desa, bagi basil pajak daerah dan retribusi daerah kabupaten/kota, bagian dari dana perimbangan keuangan pusat dan daerah yang diterima oleh kabupaten/kota, alokasi apggaran dari APBN, bantuan keuangan dari APBD provinsi dan APBD kabupaten/kota, serta hibah dan sumbangan yang tidak mengikat dari pihak ketiga.

Sumber pendapatan Desa tersebut secara keseluruhan digunakan untuk mendanai seluruh kewenangan yang menjadi tanggung jawab Desa. Dana tersebut digunakan untuk mendanai penyelenggaraan kewenangan Desaya mencakup penyelenggaraan pemerintahan, pembangunan, pemberdayaan masyarakat, dan kemasyarakatan. Dengan demikian, pendapatan Desa yang bersumber dari APBN juga digunakan untuk mendanai kewenangan tersebut. Berdasarkan Undang-Undang Nomor 6 Tahun 2014 tentang dana Desa, Desa diberikan kewenangan untuk mengatur dan mengurus kewenangannya sesuai dengan kebutuhan dan prioritas Desa. Hal itu berarti Dana Desa akan digunakan untuk mendanai keseluruhan kewenangan Desa sesuai dengan kebutuhan dan 
Vol.1 No.1 Juni 2019

prioritas Dana Desa tersebut. Namun, mengingat Dana Desa bersumber dari Belanja Pusat, untuk mengoptimalkan penggunaan Dana Desa, Pemerintah diberikan kewenangan untuk menetapkan prioritas penggunaan Dan Desa untuk mendukung program pembangunan Desa dan pemberdayaan masyarakat Desa. Penetapan prioritas penggunaan dana tersebut tetap sejalan dengan keweriangan yang menjadi tanggung jawab Desa.

Dana tersebut digunakan untuk mendanai penyelenggaraan kewenangan Desa yang mencakup penyelenggaraan pemerintahan, pembangunan, pemberdayaan masyarakat, dan kemasyarakatan. Dengan demikian, pendapatan Desa yang bersumber dari APBN juga digunakan untuk mendanai kewenangan tersebut. Berdasarkan Undang-Undang Nomor 6 Tahun 2014 tentang dana Desa, Desa diberikan kewenangan untuk mengatur dan mengurus kewenangannya sesuai dengan kebutuhan dan prioritas Desa. Hal itu berarti Dana Desa akan digunakan untuk mendanai keseluruhan kewenangan Desa sesuai dengan kebutuhan dan prioritas Dana Desa tersebut. Namun, mengingat Dana Desa bersumber dari Belanja Pusat, untuk mengoptimalkan penggunaan Dana Desa, Pemerintah diberikan kewenangan untuk menetapkan prioritas penggunaan Dan Desa untuk mendukung program pembangunan Desa dan pemberdayaan masyarakat Desa. Penetapan prioritas penggunaan dana tersebut tetap sejalan dengan keweriangan yang menjadi tanggung jawab desa.

\section{Peningkatan ekonomi}

Peningkatan berarti kemajuan, perubahan, perbaikan. Sedangkan peningkatan perekonomian yaitu suatu perubahan jenjang atau perbaikan kondisi dari perkonomian yang lemah kea rah perekonomian yang lebih baik atau mengalami kemajuan dari sebelumnya.

Menurut Wijono (2005), pertumbuhan ekonomi secara singkat merupakan proses kenaikan output per kapita dalam jangka panjang, pengertian ini menekankan pada tiga hal yaitu proses, output per kapita dan jangka panjang. Proses menggambarkan perkembangan perekonomian dari waktu ke waktu yang lebih bersifat dinamis, output per kapita mengaitkan aspek output total (GDP) dan aspek jumlah penduduk, sehingga jangka panjang menunjukkan kecenderungan perubahan perekonomian dalam jangka tertentu yang didorong oleh proses intern perekonomian (self generating). Pertumbuhan ekonomi juga diartikan secara sederhana sebagai kenaikan output total (PDB) dalam jangka panjang tanpa memandang apakah 
kenaikan itu lebih kecil atau lebih besar dari laju pertumbuhan penduduk dan apakah diikuti oleh pertumbuhan struktur perekonomian atau tidak. Pertumbuhan ekonomi yang tinggi dan prosesnya yang berkelanjutan merupakan kondisi utama bagi kelangsungan pembangunan ekonomi (Tambunan, 2001). Pertumbuhan ekonomi menunjukkan sejauh mana aktivitas perekonomian akan menghasilkan tambahan pendapatan masyarakat pada suatu periode tertentu. Dengan kata lain, perekonomian dikatakan mengalami pertumbuhan bila pendapatan riil masyarakat pada tahun tertentu lebih besar dari pada pendapatan riil masyarakat pada tahun sebelumnya. Dalam pengertian ekonomi makro, pertumbuhan ekonomi adalah penambahan Produk Domestik Bruto (PDB), yang berarti peningkatan Pendapatan Nasional/PN.

Menurut Sukirno (2011) pertumbuhan ekonomi merupakan perkembangan kegiatan dalam perekonomian yang menyebabkan barang dan jasa yang diproduksikan dalam masyarakat bertambah. Pertumbuhan ekonomi merupakan kenaikan PDB atau PNB rill. Sejak lama ahli-ahli ekonomi telah menganalisis faktor-faktor penting yang mempengaruhi pertumbuhan ekonomi. Berdasarkan kepada pertumbuhan ekonomi yang berlaku di berbagai negara dapat disimpulkan bahwa faktor utama yang mempengaruhi pertumbuhan dan pembangunan suatu negara adalah kekayaan sumber alam dan tanahnya, jumlah dan mutu tenaga kerja, barang-barang modal yang tersedia, tingkat teknologi yang digunakan dan sistem sosial dan sikap masyarakat. Beberapa teori telah dikemukakan yang menerangkan hubungan diantara faktor produksi dengan pertumbuhan ekonomi. Pandangan teori-teori tersebut diringkas sebagai berikut a) Teori Klasik. Menekankan tentang pentingnya faktor-faktor produksi dalam menaikkan pendapatan nasional dan mewujudkan pertumbuhan. Akan tetapi yang terutama diperhatikan adalah peranan tenaga kerja. Menurut mereka tenaga kerja yang berlebihan akan mempengaruhi pertumbuhan ekonomi. b) Teori Schumpeter. Menekankan tentang peranan usahawan yang akan melakukan inovasi dan investasi untuk mewujidkan pertumbuhan ekonomi. c) Teori Harrod-Domar. Mewujudkan peranan investasi sebagai faktor yang menimbulkan pertambahan pengeluaran agregat. Teori ini pada dasarnya menekankan peranan segi permintaan dalam mewujudkan pertumbuhan. d) Teori Neo-Klasik. Melalui kajian empirikal teori ini menunjukkan bahwa perkembangan teknologi dan peningkatan kemahiran 
masyarakat merupakan faktor yang terpenting yang mewujudkan pertumbuhan ekonomi.

\section{Desa}

Desa adalah suatu wilayah yang ditempati oleh komunitas manusia dalam lingkup kecil yang salain berinteraksi satu dengan yang lain, memiliki tatanan sosial yang mengatur kehidupan masyarakatnya melalui tradisi, adat istiadat dan hukumnya yang relatif mandiri. Desa kini menjadi daerah yang istimewah dan mandiri berada dalam wilayah kabupaten dan berhak berbicara atas kepenptingan sendiri sesuai dengan aspirasi dan sosial budaya masyarakat.

Desa menurut H.A.W. Widjaja dalam bukunya yang berjudul "Otonomi Desa" menyatakan bahwa: Desa adalah sebagai kesatuan masyarakat hukum yang mempunyai susunan asli berdasarkasan hak asal-usul yang bersifat istimewa. Landasan pemikiran dalam mengenai Pemerintahan Desa adalah keanekaragaman, partisipasi, otonomi asli, demokratisasi dan pemberdayaan masyarakat. Menurut R. Bintarto, berdasarkan tinjuan geografi yang dikemukakannya, desa merupakan suatu hasil perwujudan geografis, sosial, politik, dan cultural yang terdapat disuatu daerah serta memiliki hubungan timbal balik dengan daerah lain. Menurut Kamus Besar Bahasa Indonesia, desa adalah suatu kesatuan wilayah yang dihuni oleh sejumlah keluarga yang mempunyai system pemerintahan sendiri (dikepalai oleh seorang Kepala Desa) atau desa merupakan kelompok rumah di luar kota yang merupakan kesatuan.

Undang-Undang Nomor 6 Tahun 2014 Tentang Desa Pasal 1, Desa adalah Desa dan adat atau yang disebut dengan nama lain, selanjutnya disebut Desa, adalah kesatuan masyarakat hukum yang memiliki batas wilayah yang berwenang untuk mengatur dan mengurus urusan pemerintahan, kepentingan masyarakat setempat berdasarkan prakarsa masyarakat, hak asal usul, dan/atau hak tradisional yang diakui dan dihormati dalam sistem pemerintahan Negara Kesatuan Republik Indonesia.

\section{METODE}

\section{Jenis Penelitian}

Pendekatan yang digunakan dalam penelitian ini adalah metode penelitian kualitatif karena data yang dihasilkan dalam penelitian ini berupa kata-kata tertulis atau lisan. Hal ini sesuai dengan pendapat Bogdan dan Taylor dalam Moleong (2007) yang menyatakan bahwa metode kualitatif sebagai prosedur penelitian yang menghasilkan data deskriptif berupa kata-kata tertulis atau lisan dari seorang lain dan perilaku yang diamati.

Penelitian ini menggunakan pendekatan yuridis normatif 
dengan menggunakan analisis undang-undang Desa yang akan mampu menggambarkan regulasi terkait dengan keuangan desa (Suratman dan Philips Dillah 2103), kemudian menggunakan pendekatan masalah dengan menggunakan case of study (studi kasus) yaitu mengkaji peraturan mengenai keuangan desa (Bahder Johan Nasution 2008). Selanjutnya menggunakan studi kepustakaan dengan cara membaca, mengutip, menyalin dan menganalisa.

\section{Fokus Penelitian}

Fokus penelitian sangat berguna bagi penulis karena mempermudah dalam membuat keputusan yang tepat, yaitu tentang data mana yang diperlukan ataupun data mana yang tidak diperlukan dalam penulisan ini.

Berdasarkan permasalahan yang telah dirumuskan sebelumnya, maka yang menjadi fokus penelitian ini yaitu menjelaskan bagaimana pelaksanaan dan pemanfaatan dana desa dalam pembangunan yang di gambarkan melalui sejauhmana target yang telah dicapai oleh pemerintah Desa dalam pemanfaatan dana desa. Pembangunan yang dimaksud adalah pembangunan di dua aspek yaitu pembangunan fisik berupa sarana dan prasarana serta pemberdayaan masyarakat, dengan tahun anggaran 2017.

\section{Lokasi Penelitian}

Lokasi

penelitian merupakan tempat peneliti dapat melihat keadaan sebenarnya dari obyek yang akan diteliti untuk mendapatkan data-data yang akurat, sehingga akan benar-benar mendapatkan data yang berguna untuk penelitian ini. Dalam hal ini lokasi penelitian tersebut adalah di Desa Tunjungtirto Kecamatan Singosari Kabupaten Malang.

\section{Sumber Data}

Lofland dalam Moleong (2007) menyebutkan jika sumber data utama dalam penelitian kualitatif adalah kata-kata, tindakan, dan selebihnya adalah data tambahan seperti dokumen dan lain-lain. Dalam penelitian ini sumber data diperoleh dari Data Primer dan Data sekunder, dalam penelitian ini menggunakan data sekunder yang diperoleh dari arsip dan dokumen-dokumen resmi yang ada di Kantor Desa Tunjungtirto Kecamatan Singosari Malang ataupun instansi yang terkait. Selain itu juga berasal dari buku-buku, jurnal, ataupun makalah.

\section{Teknik Penentuan Informan}

Informan yang digunakan dalam penelitian ini adalah menggunakan teknik key person, dimana penggunaan teknik tersebut dilakukan karena peneliti telah mengetahui dan memahami informasi awal tentang objek penelitian maupun informan penelitian yang dimaksudkan untuk mendapatkan informasi 
sebanyak mungkin. Informan yang diambil dengan pertimbangan bahwa informan yang dipilih dianggap banyak mengetahui atau berkompeten terhadap masalah yang dihadapi, informan diambil dengan maksud tidak mesti manjadi wakil dari seluruh populasi, tetapi informan memiliki pengetahuan yang cukup, serta mampu menjelaskan keadaan sebenarnya tentang objek penelitian, Oleh sebab itu, informan yang dimaksud adalah a) Kepala Desa Tunjungtirto Kecamatan Singosari Kabupaten Malang, Menjadikan Kepala Desa Tunjungtirto sebagai salah satu informan karena secara hierarki Kepala Desa adalah penanggungjawab segala bentuk pemanfaatan dari dana desa. Sebagai pemberi informasi mengenai jumlah anggaran, pemberi data-data desa dan juga menjelaskan alokasi dana desa. b) Tokoh Pemuda, Tokoh Perempuan, dan Tokoh Masyarakat Desa Tunjungtirto Menjadikan beberapa tokoh yang ada di Desa Tunjungtirto sebagai informan karena dianggap memiliki kapasitas dan pengetahuan yang cukup tentang dana desa. Tokoh Pemuda, Tokoh Perempuan, dan Tokoh Masyarakat Desa Tunjungtirto memberikan informasi tentang perubahanperubahan khususnya dibidang perekonomian pembangunan yang ada pada desanya setelah adanya dana desa. c) BPD Desa
Tunjungtirto, Badan Permusyawaratan Desa dipilih sebagai salah satu informan karena secara hierarki merupakan bagian dari pemerintah desa yang bertugas untuk mengawasi kegiatan dari pemerintah desa dan menyalurkan aspirasi-aspirasi masyarakat. d) Masyarakat, Menjadikan masyarakat sebagai salah satu informan karena masyarakat merupakan subjek dan objek dari pemanfaatan dana desa tersebut.

\section{Teknik Pengumpulan Data}

Untuk memperoleh datadata yang diperlukan dalam penelitian ini, maka peneliti menggunakan tiga teknik dalam pengumpulan data sesuai dengan jenis penelitiannya yakni penelitian diskriptif dengan pendekatan kualitatif, yaitu wawancara, observasi, dan dokumentasi.

\section{Analisis Data}

Teknik analisa yang digunakan dalam penelitian ini adalah menggunakan analisa model interaktif. Menurut Miles dan Huberman (2005), dalam analisa model interaktif ada tiga kelompok analisis, yaitu reduksi data, sajian data, dan penarikan kesimpulan. Analisa ini dilakukan dalam bentuk interaktif pada setiap komponen utama tersebut: a) Reduksi Data, adalah proses pemilihan, pemusatan pada penyederhanaan, pengabstrakan, dan transformasi data kasar yang muncul dari catatan tertulis di 
lapangan. Reduksi data digunakan untuk menyederhanakan data agar dapat dengan mudah dipahami. Oleh karena itu reduksi data merupakan suatu bentuk analisis yang menyatukan, menggolongkan, mengarahkan, dan membuang yang tidak perlu. b) Penyajian Data (display data), yang dimaksudkan adalah sebagai sekumpulan informasi yang tersusun, yang memberikan kemungkinan adanya penarikan kesimpulan dan pengambilan tindakan. Dengan penyajian data ini, kita dapat memahami apa yang sedang terjadi dan apa yang harus kita lakukan. Hal ini dilakukan agar memudahkan bagi peneliti untuk melihat gambaran secara keseluruhan atau bagian-bagian tertentu dari data penelitian, sehingga dari data tersebut dapat ditarik kesimpulan. Adapun bentuk penyajian data yang paling umum digunakan adalah bentuk teks uraian. b) Penarikan kesimpulan (verifikasi data), dalam penelitian kualitatif dilakukan secara terus menerus sepanjang proses penelitian berlangsung. Dapat dikatakan bahwa penarikan kesimpulan merupakan suatu kegiatan dari konfigurasi yang utuh selama peneltian berlangsung. Dari hasil data-data yang diperoleh dari lapangan tersebut kemudian dikumpulkan serta dianalisis untuk dapat ditarik kesimpulannya.

\section{HASIL DAN PEMBAHASAN}

Sesuai dengan amanat Undang-Undang Nomor 6 Tahun 2014 tentang Desa, Pemerintah mengalokasikan Dana Desa, melalui mekanisme transfer kepada Kabupaten/Kota. Berdasarkan alokasi Dana tersebut, maka tiap Kabupaten/Kota engalokasikannya ke pada setiap desa berdasarkan jumlah desa dengan memperhatikan jumlah penduduk. Lebih lanjut dalam Pasal 74 UU Desa disebutkan, belanja desa dimana dana desa menjadi sumber utama pendapatan desa diprioritaskan untuk memenuhi kebutuhan pembangunan yang disepakati dalam musyawarah desa dan sesuai dengan prioritas pemerintah kabupaten/kota, pemerintah provinsi, dan pemerintah. Selain itu, pasal $78 \mathrm{UU}$ Desa menyatakan, pembangunan desa bertujuan meningkatkan kesejahteraan masyarakat desa dan kualitas hidup manusia serta penanggulangan kemiskinan melalui pemenuhan kebutuhan dasar, pembangunan sarana dan prasarana desa, pengembangan potensi ekonomi lokal, serta pemanfaatan sumber daya alam dan lingkungan secara berkelanjutan.

Penerimaan dana desa yang diterima oleh Tunjungtirto selama tiga tahun terahir mulai tahun 2015 sampai dengan tahun 2017, menunjukkan bahwa kontribusi 
dana desa terhadap pendapatan desa semakin signifikan seperti pada table 2 .

Tabel 2. Penerimaan Dana Desa Tunjungtirto 2015-2017

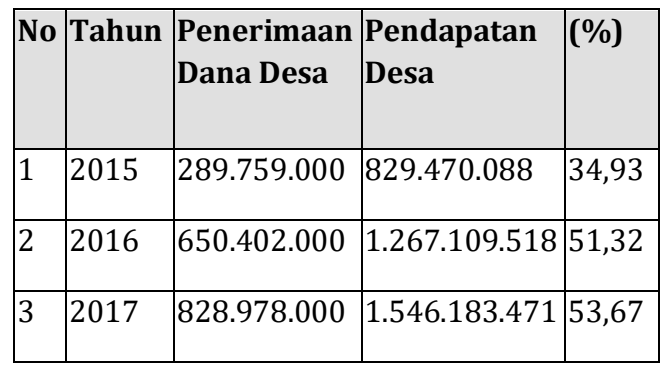

Sumber : APBDES 2015-2017

Pelaksanaan penggunaan khususnya di bidang ekonomi pada Dana Desa di Tunjungtirto dalam pembangunan selama tiga tahun terahir mulai tahun 2015 sampai tahun 2017 dapat dilihat pada tabel 3 .

Tabel 3. Pelaksanaan dana desa dalam pembangunan pada bidang ekonomi Tahun 2015-2017

\begin{tabular}{|c|l|l|}
\hline Tahun & Kegiatan & Jumlah Biaya \\
\hline 2015 & $\begin{array}{l}\text { Perbaikan } \\
\text { gedung sarana } \\
\text { pusat } \\
\text { perekonomian } \\
\text { masyarakat }\end{array}$ & 97.255 .400 \\
\hline 2016 & $\begin{array}{l}\text { Pembangunan } \\
\text { pusat sarana } \\
\text { perekonimian } \\
\text { masyarakat }\end{array}$ & 100.000 .000 \\
\hline 2017 & $\begin{array}{l}\text { Penyertaan } \\
\text { modal } \\
\text { Bumdes }\end{array}$ & 170.240 .015 \\
\hline
\end{tabular}

Sumber: APBDES 2015-2017
Dari data tabel 3, maka diketahui penggunaan dana desa untuk pembangunan pada bidang ekonomi, Sejak tahun 2018 prioritas anggaran desa tak lagi untuk pengentasan kemiskinan, kesehatan, pendidikan dan infrastruktur saja. Tetapi juga menghidupkan Badan Usaha Milik Desa (BUMDes) yang sudah memiliki empat unit usaha berupa pengelolaan sampah, simpan pinjam, pusat kuliner dan Usaha Kecil Menengah (UKM). Anggaran untuk pelatihan pemberdayaan masyarakat dan Pameran Hasil Usaha Ekonomi Masyarakat sekitar Rp. $121,528,000$.

Desa Tunjungtirto sudah mempunyai Badan Usaha Milik Desa Tunjungtirto (BUMDesa) "MAJU BERSAMA" yang gedungnya berlokasi di jl perusahaan barat hotel grage losawi desa Tunjungtirto Singosari Malang semakin mengembangkan unit usahanya. Awalnya sudah memiliki unit usaha simpan pinjam kini berkembang lagi memiliki unit usaha tunjungtirto bersih yang mengelola penarikan sampah dilingkungan, unit usaha pupuk yang memfasilitasi kebutuhan para petani berupa pengadaan pupuk dan alat pertanian, unit usaha sembako yang menjual kebutuhan sembako dengan harga terjangkau serta unit usaha home industri memasarkan produk hasil olahan masyarakat pemilik usaha kecil. Desa Tunjungtirto merupakan desa dengan lokasi yang strategis 
karena berbatasan langsung dengan kota malang, dilalui oleh jalur alternatif lintas barat menuju kota batu serta mulai tumbuhnya fasilitas perhotelan dan sarana pendidikan yang tentunya menyerap para wisatawan untuk datang didesa tunjungtirto dan hal ini merupakan potensi yang bisa ditangkap dan dikembangkan oleh tunjungtirto melalui BUMDesa untuk mengembangkan segala potensi yang punya nilai jual tinggi sehingga bisa mendatangkan nilai tersendiri bagi taraf hidup masyarakat melalui pengelolaan aset dan potensi desa yang sesuai perkembangan jaman. Dengan adanya bumdesa ini diharapkan agar siklus pertumbuhan ekonomi di desa tunjungtirto semakin tinggi sehingga dapat membantu meningkatkan kesejahteraan masyarakat. Mengingat lokasinya yang sangat strategis maka diharapkan mampu mendongkrak system ekonomi masyarakatnya.

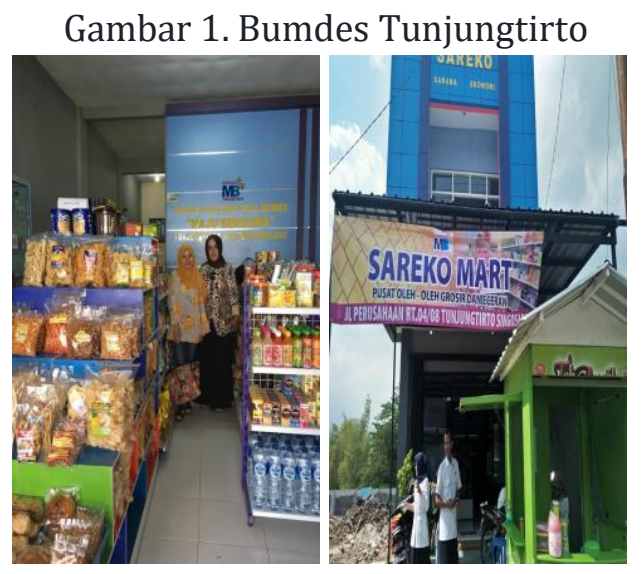

\footnotetext{
Bumdes Tunjungtirto menjual berbagai hasil kreatif masyarakatnya, ada pun barang-
}

barang hasil kreatif masyarakat adalah kreasi kain perca, gerabah, makanan ringan, kreasi rotan, dll. Melalui pemberdayaan masyarakat dan pelatihan memberikan keterampilan kepada masyarakat sehingga mampu mengolah limbah menjadi barang siap jual, atau pun hasil alam sekitar sehingga menjadikan makanan ringan.

Gambar 2. Produk hasil olahan ketrampilan

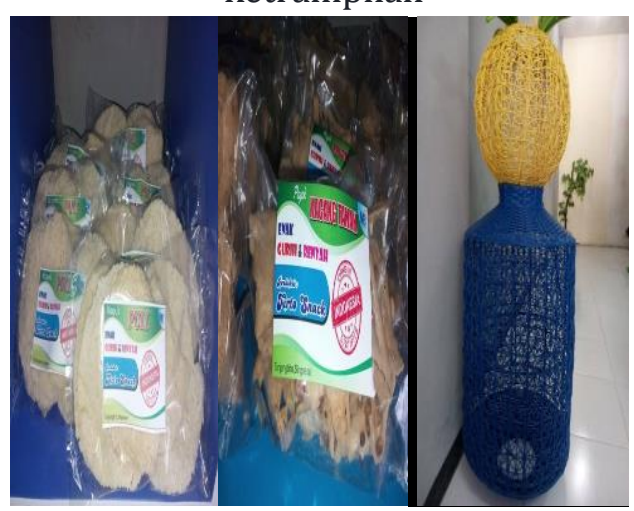

Dari hasil kreatif masyarakat di atas maka menunjukan bahwa desa Tunjungtirto sudah mempunyai produk unggulan yang sudah tertata pada aspek produksi, distribusi dan pemasaran, Dan kegiatan pelatihan tersebut adalah salah satu kegiatan dari penyerapan dana desa untuk pemberdayaan masyarakat. Sasaran penggunaan Dana Desa adalah untuk memperbaiki kehidupan masyarakat desa, terutama dalam segi ekonomi, sosial, budaya dan politik. Partisipasi masyarakat merupakan salahsatu aspek utama dari penggunaan dana desa. 
Penggunaan dana desa dirumuskan dalam musyawarah desa, serta alokasi anggaran dimasukkan dalam APBDesa. Tidak hanya pemasaran melalui Bumdes tunjungtirto tetapi juga selalu mengikuti pameran-pameran yang ada di kota Malang dan sekitarnya, hal ini cukup menambah pendapatan masyarakat.

Selain

Bumdes

pemberdayakan masyarakat, desa tunjungtirto mengalokasikan dana ADD untuk pemberdayaan masyarakat dalam bidang peningkatan sosial dan ekonomi masyarakat yaitu dengan peningkatan peranan wanita melalui perwujudan kesetaraan gender dan Pemberdayaan dan Kesejahteraan Keluarga (PKK) Desa. Dalam mendorong peningkatan sosial dan ekonomi masyarakat dapat dilakukan melalui kegiatan-kegiatan dari PKK, yang bertujuan meningkatkan pendapatan keluarga dengan kemandirian berikut salah satu hasil kreasi PKK desa Tunjungtirto.

Gambar 3. Hasil kreasi PKK yang siap dipasarkan

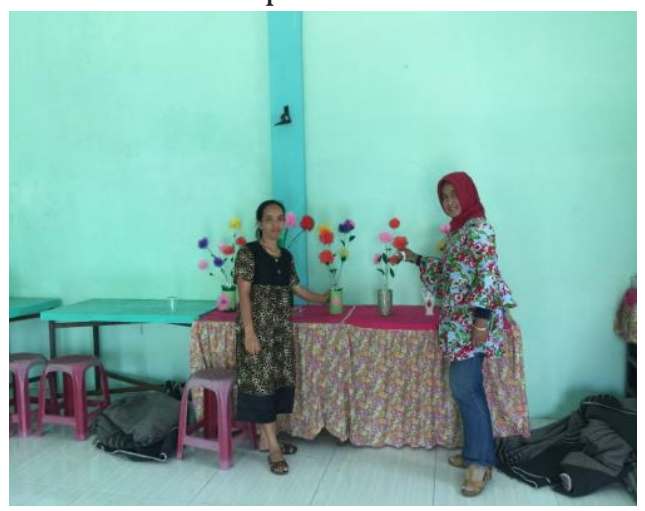

Inovasi lainnya untuk mendongkrak perekonomian masyarakat desa tunjungtirto, pemerintah desa membuat kampung tematik atau Mural. Mural berasal dari bahasa latin Murus yang berarti Dinding. Arti yang lebih luas lagi, Mural adalah lukisan yang dilukis pada bidang permanen seperti tembok, dinding dan sejenisnya. Mural sudah ada sejak zaman dulu, dipergunakan sebagai ajang kegiatan spiritual dan ajang eksistensi diri. Awal mula Berdirinya Kampung Mural itu sendiri dikarenakan banyak seniman-seniman jalanan yang jumlahnya cukup banyak di Dusun Losawi, Desa Tunjungtirto. Mereka tidak mendapatkan wadah berkreasi yang dapat menampung kreatifitas mereka. Mulai dari artist vandal, pelaku grafitty yang biasa disebut bomber dan seniman mural itu sendiri. Tujuan berdirinya kampung mural salah satunya adalah mengubah sudut pandang masyarakat terhadap seniman jalanan dengan cara memfasilitasi para seniman. Dengan memberi fasilitas berupa media berkreasi pada para seniman diharapkan masyarakat dapat mengubah sudut pandang terhadap seniman jalanan menjadi lebih positif, lebih respek, dan lebih mengapresiasi karya mereka.

Adanya kampung mural ini tidak hanya menjadikan para seniman jalanan mendapat tempat 
berkreasi saja tetapi juga bisa menjadikan tempat untuk mendapatkan rejeki. Karya-karya mereka telah banyak dilirik oleh masyarakat luas. Karya mural ini juga telah merubah kampung yang biasa-biasa saja menjadi kampung yg indah, bersih, dan bernilai seni serta mampu mendatangkan wisatawan yang hendak menikmati karya para seniman di Dusun Losawi ini. Kedatangan para wisatawan ini membawa keuntungan tersendiri bagi warga setempat. Selain menambah eksistensi daerah juga brdampak pada ekonomi warga. Tak jarang saat berjalan-jalan menikmati karya para seniman, para wisatawan membeli produk unggulan desa untuk dijadikan oleh-oleh. Selain itu munculnya kampung mural juga menambah rasa kebersamaan, saling menjaga, dan keguyuban antar warga, berikut gambar kampong tematik yang ada di desa Tunjungtirto.

Gambar 4. Kampung tematik

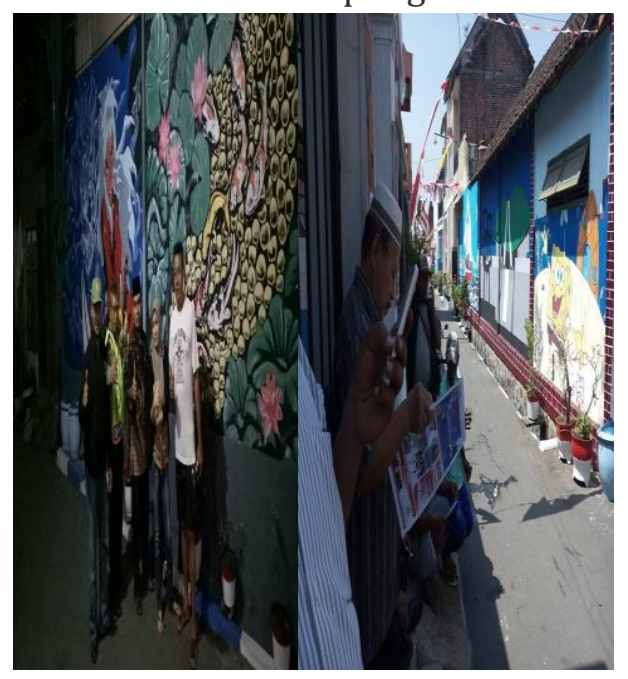

Warga kampung mural
cukup ramah terhadap para wisataan. Warga dan juga para seniman kampung mural berharap agar warga dan wisatawan yg datang ke kampung mural bisa lebih menghargai dan mencintai karya seniman jalanan serta menjaga lingkungan agar tetap cantik dan menarik. Pemerintah Desa Tunjungtirto sangat mensupport adanya kampung mural yang ada di Dusun Losawi ini, pemerintah desa berharap agar kampung mural bisa bersaing dengan kampung-kampung tematik lainnya. Namun yang perlu menjadi perhatian lebih dalam adalah perlu adanya pemberdayaan dan edukasi masyarakat dengan adanya sanggar seni atau pelatihanpelatihan terkait pembuatan souvenir dan oleh-oleh wisata lainnya agar masyarakat dapat meningkatkan taraf hidupnya dan memanfaatkan potensi yang ada di sekitarnya.

\section{E. SIMPULAN DAN SARAN}

\section{Kesimpulan}

Ada beberapa kesimpulan dari hasil penelitian ini yaitu adanya peningkatan Dana Desa setiap tahunnya dan di kelolah dengan baik oleh Desa Tunjungtirto dan pemanfaatan Anggaran Dana Desa pada bidang ekonomi masyarakat adalah tersedianya tempat penjualan berbagai hasil produksi rumah tangga masyarakat Desa 
Tunjungtirto, dan juga dengan Anggaran Dana Desa di bidang ekonomi digunakan untuk kegiatan peningkatan peranan wanita melalui perwujudan kesetaraan gender dan Pemberdayaan dan Kesejahteraan Keluarga (PKK) Desa. Dalam mendorong peningkatan sosial dan ekonomi masyarakat dapat dilakukan melalui kegiatankegiatan dari PKK, yang bertujuan meningkatkan pendapatan keluarga dengan kemandirian.

Inovasi lainnya untuk mendongkrak perekonomian masyarakat desa tunjungtirto, pemerintah desa membuat kampung tematik atau mural yaitu kampung yang ditata sedemikian rupa menjadi menarik sehingga di harapkan menjadi tempat wisata dengan demikian maka akan mendorong pergerakan ekonomi masyarakat.

\section{Saran}

Dalam

kegiatan peningkatan ekonomi masyarakat pemerintah Desa Tunjungtirto dapat bekerjasama dengan pihakpihak tertentu Untuk lebih mengoptimalkan lagi pemanfaatan Anggaran Dana Desa dalam meningkatkan perekonomian, selain itu pemerintah Desa Tunjungtirto perlu memperhatikan beberapa hal seperti lebih meningkatkan promosi di bazarbazar yang di lakukan di kota atau di luar kabupaten Malang.

\section{DAFTAR PUSTAKA}

A.W. Widjaja, 1996, Pemerintahan Desa dan Administrasi Desa Menurut Undang-Undang Nomor 5 Tahun 1979 (sebuah Tinjauan), Jakarta, PT Raja Grafindo Persada.

Bahder Johan Nasution, 2008, Metode Penelitian Ilmu Hukum, Bandung, Mandar Maju.

Bintarto, 1983, Interaksi DesaKota dan Permasalahannya, yogyakarta: Ghalia Indonesia

Moleong, Lexy J. 2007. Metodologi Penelitian Kualitatif. Bandung: Remaja Rosdakarya.

Peraturan Mentri Dalam Negeri Nomor 4 Tahun 2007 tentang Pedoman Pengelolaan Kekayaan Desa

Peraturan Menteri Dalam Negeri Nomor 37 Tahun 2007 tentang Pedoman Pengelolaan Keuangan Desa Peraturan Pemerintah Nomor 72 Tahun 2005 tentang Desa

Peraturan Pemerintah Nomor 43 Tahun 2014 tentang Desa Pasal 93

Sukirno, Sadono. 2011. Makro Ekonomi Teori Pengantar Edisi Ketiga. Rajawali Pers, Jakarta

Suratman \& H.Philips Dillah, 2013, Metode Penelitian Hukum, Bandung: Alfabeta.

Tambunan, Tulus. 2001.

Perekonomian Indonesia: 
Vol.1 No.1 Juni 2019

Teori dan Temuan Empiris.

Ghalia Indonesia. Jakarta.

Undang-Undang Nomor 6 Tahun 2014 Tentang Desa.

Undang-Undang Nomor 23 Tahun 2014 tentang Pemerintahan Daerah.

Wijono, Wiloejo, Wiryo. 2005. Mengungkap SumberSumber Pertumbuhan Ekonomi Indonesia Dalam Lima Tahun Terakhir, Jurnal Manajemen dan Fiskal, Volume V, Nomor 2, Jakarta. 